\title{
Reflection of University Extra-Curricular Activities of a Candidate in Employee Selection: A Descriptive Study of HRM Related Jobs
}

\author{
P. N. K. Siriwardhana ${ }^{1}$ and T. D. Weerasinghe ${ }^{2}$ \\ ${ }^{1,2}$ Department of Human Resource Management, \\ Faculty of Commerce and Management Studies, University of Kelaniya, Sri Lanka \\ ${ }^{1}$ Naveen.siriwardhana@yahoo.com, ${ }^{2}$ tdtmdananjaya@gmail.com
}

\begin{abstract}
The main purpose of this study was to identify whether there is a significant value given to the graduates who have engaged in university extracurricular activities in the selection process for a Human Resource Management related job. Further, the current study was designed to identify the industry perception about graduates those who have engaged in extracurricular activities, and who did not. This is a cross sectional descriptive research in nature. A standard questionnaire was used to collect the primary data through a survey. The respondents were the professionals who are directly engaging in the selection process selected from 40 private sector organizations in Sri Lanka. Descriptive statistics, paired sample t-test and one-way ANOVA were used to analyze the data and make conclusions. Findings revealed that the private sector organizations significantly believe that graduates who have engaged in university extracurricular activities might have developed more skills, good personal qualities and other relevant employability behaviors than graduates those who haven't engaged. Thought the belief was that, further, it was identified the engagement in extracurricular activities is not a significant reason to get selected for a HR related job in the industry. It was found that the perception regarding undergraduates who have not engaged in extracurricular activities is not varying from industry to industry. But, findings revealed that the perception, and the given due recognition for undergraduates who have engaged in extracurricular activities is industry specific.
\end{abstract}

Keywords: University Extracurricular Activities, HR Related Jobs, Graduates

\section{Introduction}

In recent years recognition of the importance of Human Resource Management (HRM) to a company's overall performance has grown dramatically. According to Opatha (2012) human resources are the most important resource from all the resources which are used by an organization to accomplish its goals. Ability to accomplish the goals of the organization occurs because of availability of other resources such as money, machines, materials, methods, time and information. However, actual accomplishment of the goals occurs only if human resources are available. All other resources are collected, combined, and used only by human 
resources through making decisions. In fact, other resources make things possible but only human resource make things happen.

Selection is a major HRM function which helps to generate an appropriate and contented employee force in the organization. Selection of employees is a process that has got strong influence over the success of any organization. According to Opatha (2012), selection is the process of making the choice of the most appropriate person from the pool of applicants recruited to fill the relevant job vacancy. In other words employee selection is the process of putting right men on right job. It is a procedure of matching organizational requirements with the skills and qualification of people.

Nowadays employers looking to hire new employees look for specific skills, attitudes and qualities in new workers in hopes of creating or maintaining an efficient, professional and productive workplace. Skills, attitudes and personal qualities have become more important to get a job when comparing with the past. Most of the job advertisements specifically mention the skills and personal qualities that are required to successfully perform the job.

While getting the academic knowledge from the university, undergraduates can engage in extracurricular activities and improve their skills, attitudes and personal qualities which will be essential to do a job. In universities there are numerous extracurricular activities such as sports (track \& field, cricket, basketball, volleyball etc), student associations (Student council, Buddhist council etc), clubs (Toast Masters, Gavel etc), student publications and service organizations that undergraduates can be engaged.

Some undergraduates sacrifice their valuable time and engage in extracurricular activities, and also universities encourage undergraduates to engage in sports, clubs and other extracurricular activities by spending lots of money on sports equipment, workshops, and training programs and to provide other relevant facilities. According to the Annual Report of University of Kelaniya (2011) there are 23 types of sports, 38 Men \& Women teams, and total of 1500 undergraduates involved at recreational 
level of sports. Also University conducts plenty of leadership training workshops for team captains \& vice-captains, sport education segment, interfaculty sports programme, annual road race, physical fitness test and annual colors awarding ceremony for 212 undergraduates.

After completing the degree and applying for a job all graduates have same academic qualification but graduates who have engaged in extracurricular activities have got better skills, attitudes and personal qualities than the graduates who didn't make efforts to engage in extracurricular activities. Therefore, graduates who have already engaged with university extracurricular activities should get more chance of being selected for a job, but if organizations don't consider about the applicants extracurricular achievements in selection process then there will not any advantage from university extracurricular activities to get a job. Having considered all the aforementioned evidence, problem of the current research was identified as:

Whether the industry gives an additional value to the graduates those who have engaged with university extracurricular activities in their respective employee selection decisions in comparison to those who have not engaged in university extracurricular activities?

\section{Objectives of the Study}

The main purpose of this study was to identify whether there is a significant value given to the graduates those who have engaged in university extracurricular activities in the selection process of HR related job in private sector organizations in Sri Lanka. Further, two specific objectives were established in order to accomplish this main purpose:

i. To identify the perceptual differences of the industry about graduates those who have engaged in extracurricular activities and those who haven't engaged.

ii. To identify the extent of reflection of university extra-curricular activities of a candidate in the employee selection process. 


\section{Literature Review}

Nowadays HRM is becoming one of the most important fields in organizational management. Arulrajah \& Opatha, (2012) stated how HRM is becoming a significant professional role. Establishment of separate academic departments for HRM in Sri Lankan universities including University of Sri Jayewardenepura, University of Kelaniya, and University of Colombo and introduction of HRM degree programs and specializations in HRM by Sri Lankan universities and technical colleges reflect increasing importance and consideration on HRM as an academic discipline in addition to practice. Like other fields such as Accounting and Engineering, HRM is being recognized as a prestigious and significant professional field.

As far as levels of education are concerned, it starts from G. C. E. (O/L) to end up with postgraduate qualification (e.g. MBA). In between these two levels there are several levels including Bachelor's Degrees in HRM, Business Management, Commerce and other levels such as Certificates, Diploma in HRM that are needed to be possessed by job seekers to apply for management trainees in Sri Lanka. For entry level HRM jobs educational qualification is one of the top requirements to enter into the job (Arulrajah \& Opatha, 2012).

\subsection{Essential Skills Needed to Perform a Job}

Apart from the educational qualifications, there are necessary skills which help to perform a job successfully. Yorke (2007) defined the employability as the possession of skills and attributes above and beyond a good academic qualification. Moreover, Poon (2012) cited evidence from Archer and Davison (2008) and mentioned that the most common employability skills identified are: integrity, intellectual, ability, confidence, character/personality, planning and organizational skills, and analysis \& decision-making skills. Hashim (2012) cited evidence from Knight (2005) and stated that when hiring graduates, employers generally value: the ability of coping with uncertainty; ability to work under pressure; action-planning skills; communication skills; IT skills; proficiency in networking; readiness to 
explore and create opportunities; self-confidence; self-management skills; and willingness to learn. Further, Hashim (2012) mentioned that employers today concern about finding good workers who are not only possess a basic academic qualification, but also looking for employees with personal qualities and skills including: self-confidence, self-control, social skills, honesty, integrity, adaptability and flexibility, team spirit, punctuality, efficiency, self-directedness, good work attitude, well-groomed, cooperativeness, self-motivation, and self-management.

\subsection{Essential Skills and Personal Qualities Required to Perform a HRM Related Job}

As cited in Arulrajah \& Opatha, (2012) Opatha (2008; 2009) has pointed out seven competencies required to perform a HR related job. In addition to the technical competence of HRM a human resource manager should possess competencies which include human relations competence (communicating, motivating, influencing people to change and leading), conceptual competence (planning, organizing and controlling), intelligence (mental reasoning ability), appropriate personality (interest in people, appreciation in human capital, desire for developing people, pleasing appearance, adjustable and flexible, self- monitoring, extroversion to a certain extent), individual good character (moral excellence, ability to build and enhance virtues of responsibility, honesty, tolerance, patience, humility, etc. and minimize or eradicate vices of jealousy, greed, anger, stinginess, deception, corruption, retaliation etc.), and personal/individual management competencies (ethical thinking, positive thinking, continuous learning, balancing life and the work, time management skills, career management, and stress management). Out of these competences human relation competency, appropriate personality, intelligence and good character are highly related to personal qualities or characteristics of HR professional.

In the literature there were very few scholars who had mentioned about personal qualities, characteristics, attributes which are needed to perform HRM related job. Opatha \& Arulrajah (2012) conducted an exploratory study using all the HRM related employment advertisements appeared in the Sunday Observer newspaper for 
the period of 5 years $(2006,2007,2008,2009$ and 2010) and found that HRM field at entry-level in the Sri Lankan context, out of 29 skills, communication skills, computer literacy/IT skills, interpersonal skills, analytical skills, human relations skills, leadership skills, ability to work long hours, public relation skills, presentation skills and ability to work independently are the top ten skills companies expect from entry-level HRM candidates.

Dynamic, team player/oriented/team spirit, motivated/self-motivated, and results oriented were commonly and very frequently stated/expected four personal qualities by the organizations irrespective of different HRM jobs in Sri Lanka. The label 'common personal qualities' could be given to the above motioned four identified qualities.

\subsection{Relationship between Extracurricular Activities and Employability}

\section{Skills}

Gilman (2004) revealed that one of the main goals of extracurricular activities in Universities is skills acquisition. Felfe, Schyns \& tymon (2014) cited evidence from Stiwne and Jungert (2010) and mentioned that even students themselves recognize that the best opportunities to learn such generic skills and cultural values are provided in extra-curricular activities. According to Lawhorn (2008-09) Athletics, clubs, and other extracurricular activities have benefits beyond the enjoyment they provide. These pursuits assist students in developing personally, socially, and intellectually. They might even help students to advance their academic and professional goals. Mayer \& Chen (2001) stated that managers should concern with the perception of female and male employees who have participated in sports because sports can help individuals bring necessary skills such as goal setting, leadership, competitiveness, fair play, and networking to the workplace. Wilson (2009) found that students in out-of-school activities can learn skills such as teamwork, leadership skills, and can decrease the likelihood of being involved with problem behaviors. 
Lawhorn (2008) stated some of the extracurricular activities and the skills which they help to develop as discussed below.

Academic clubs and associations: In high schools and colleges, many academic subjects have a related club. These clubs promote their members' shared interest in the subject and supplement classroom learning. Club members may hold leadership positions and arrange to invite guest speakers, take field trips, or organize study groups.

Academic clubs provide students with an opportunity to discuss topics beyond the scope of the classroom. Language clubs, for example, allow students to watch foreign films or eat delicacies that are native to the country of origin. These cultural experiences are enjoyable and help make learning a language more meaningful.

Academic competition: Not all competition takes place on fields and in gymnasiums. Many schools offer students the chance for intellectual contests.

Academic competitions might be limited to a single subject, such as mathematics or history, or cover a broad range of subjects. Competitions may take place within a single school, or school teams might participate in State, national, or international events. Academic competitions usually require significant preparation. It is likely that the study skills of students who are selected for the team are already well developed; however, competitions give them the chance to hone these skills further. Participants also learn to work together with other team members.

Athletics: Athletics are among the most prominent and popular of extracurricular activities in both high school and college. Participation in varsity athletics usually requires major commitments of time and effort. But many students take part in another popular option: intramural sports.

Although intramural athletics may not require the same commitment as varsity sports, both help students develop the same kinds of skills. In team sports, for example, participants usually develop a sense of camaraderie and learn to work 
together with others. And physically active students learn to appreciate the benefits of an active lifestyle.

Debating: Debating sometimes called forensics, requires a wide range of skills. In debate competitions, participants present an argument they have researched, based on established topics and rules. High school and college debate teams might compete intramurals or against other schools.

Debaters must have strong research skills, be able to think quickly, and be able to communicate well. In addition, debaters must be comfortable performing in front of an audience and having the confidence to do so is a valuable workplace skill, especially when it comes to making presentations to coworkers or superiors.

Debate clubs help students develop analytical and logical reasoning skills, as well as the ability to think and speak extemporaneously. Both colleges and employers value these skills. Students interested in law-related or political occupations in which effective debate skills are critical are especially likely to benefit from participation in debate.

Student Publications: Most schools have opportunities for interested writers: Publications by students and for students offer future writers and editors a chance to gain experience and build a portfolio. Newspapers, yearbooks, and literary magazines are common publications in high school and college.

These publications allow students to practice writing and editing, learn basic publishing methods, and, in the process, produce a source of information for their classmates. Many entry-level writing jobs require applicants to submit published articles, known as clips and working on a student publication provides a good source of material for such articles.

Performing Arts: Most high schools and colleges have performing arts organizations, such as music (band, orchestra, and chorus) and drama clubs. Like elite athletes, student performers usually must make a major time commitment. This includes time with the group and, often, individual practice time. These performers 
don't just play for their own benefit, however: Many also take part in group competitions between schools. Both musical and theater organizations may compete in festivals around the Nation. Such performances allow students to receive feedback from judges and share their work with peers from other programs. Not all members of these groups perform onstage. Backstage and other support activities allow nonperformers to pursue their interests while helping to work toward the shared goal of a successful concert, play, or other performance.

Other Organizations: There are other ways for students to get involved in organized activities outside the classroom. Examples include honor societies, clubs affiliated with political parties, and, on college campuses, fraternal social organizations (fraternities and sororities). Like many extracurricular activities, the activities offered by these groups promote social interaction with like-minded peers. They also provide students with other opportunities, such as leadership development and community service.

\section{Materials and Methods}

Since this study is designed to describe and compare the industry perception and the chance of getting a HR related job by graduates who have engaged in university extracurricular activities and who did not engage in extracurricular activities, the nature of this study is considered as descriptive. This is a cross sectional field study about graduates who have engaged in university extracurricular activities and who did not which has done rooted in the HR field in Sri Lanka.

The target population of this research is private sector organizations which are providing job opportunities to graduates in Human Resource Management field. Since there is an unknown population of private sector organizations researcher has selected 40 private sector organizations as the sample of this study using the convenient sampling method.

For the purpose of collecting primary data, questionnaire is developed by the researcher based on the skills and personal qualities need to perform HR related job which were stated at Opatha \& Arulrajah (2012). Questionnaires were distributed to 
officers who are directly engage in the selection process in 40 private sector organizations in Sri Lanka.

There are two open-ended questions to get the information about the name of the organization and the industry. The overall questionnaire was organized into two sections as 'section I' and 'section II'. Both sections consist of five point Likert Scale questions and there were 10 questions per each section. Those 10 questions reflect the industry perception about skills and personal qualities of a graduate and the chance of selecting for the job in their industry. 'Section I' was designed to gather data about undergraduates who have engaged in university extracurricular activities while 'section II' developed to gather relevant information about graduates who have not engaged in university extracurricular activities. A five point Likert Scale questions is used in the questionnaire at "section I" and "section II". Collected data from questionnaires were analyzed using Statistical Package for Social Science (SPSS) version 20.

The construct validity of the measurements of this study was guaranteed by doing a factor analysis which loaded more than 0.60 levels for all the measurements. To measure the reliability of the questionnaire Cronbach's Alpha technique was applied. The coefficient of Cronbach's Alpha values of the questionnaire was more than 0.7 . The results of reliability and validity tests showed that the questionnaire was valid and could reliable.

Table 01: Reliability analysis results of the items in section I (graduates who have engaged in university extracurricular activities)

\begin{tabular}{|c|c|}
\hline Cronbach's Alpha & No. of Items \\
\hline $\mathbf{8 4 6}$ & 10 \\
\hline
\end{tabular}

Source: Survey Data, 2015 
Table 02: Reliability analysis results of the items in section II (graduates who have not engaged in university extracurricular activities)

\begin{tabular}{|c|c|}
\hline Cronbach's Alpha & No. of Items \\
\hline $\mathbf{. 7 4 3}$ & 10 \\
\hline
\end{tabular}

Source: Survey Data, 2015

\section{Results and Discussion}

Descriptive statistics were used to find out statistical measures such as mean value which was used to identify the industry perception about graduates who have engaged in university extracurricular activities and graduates who have not engaged in university extracurricular activities. Furthermore, through descriptive statistics undergraduate's chance of selecting for a HR related job was measured. Paired sample $\mathrm{T}$ - test was performed to identify the significant difference of aforementioned two groups. To test the significance of the model ANOVA table was used.

Table 03: Descriptive statistics of the industry perception about graduates who have engaged in university extracurricular activities

\begin{tabular}{|ll|c|c|}
\hline & & Statistic & Std. Error \\
\hline & Mean & 3.8000 & .05733 \\
& Median & 3.8182 & \\
& Variance & .131 & \\
Undergraduates & Std. Deviation & .36259 & \\
Engaged in University & Minimum & 2.82 & \\
Extracurricular & Maximum & 4.36 & \\
activities & Range & 1.55 & \\
& Interquartile Range & .43 & \\
& Skewness & -.797 & .374 \\
& Kurtosis & .847 & .733 \\
\hline
\end{tabular}

Source: Survey Data, 2015 
According to the table 03, mean of the industry perception of graduates who have engaged in extracurricular activities is 3.8 while the median is 3.8182 and minimum and maximum values are 2.82 and 4.36 respectively.

Table 04: Descriptive statistics of the industry perception about graduates who have not engaged in university extracurricular activities

\begin{tabular}{|c|c|c|c|}
\hline & & Statistic & Std. Error \\
\hline \multirow{10}{*}{$\begin{array}{l}\text { Undergraduates } \\
\text { not Engaged in } \\
\text { extracurricular } \\
\text { activities }\end{array}$} & Mean & 3.0795 & .09424 \\
\hline & Median & 3.0909 & \\
\hline & Variance & .355 & \\
\hline & Std. Deviation & .59602 & \\
\hline & Minimum & 1.55 & \\
\hline & Maximum & 4.36 & \\
\hline & Range & 2.82 & \\
\hline & Interquartile Range & .89 & \\
\hline & Skewness & -.202 & .374 \\
\hline & Kurtosis & -.039 & .733 \\
\hline
\end{tabular}

Source: Survey Data, 2015

According to the table 04, mean of the industry perception of graduates who have not engaged in university extracurricular activities is 3.0795 while the median is 3.0909 and minimum and maximum values are 1.55 and 4.36 respectively.

When comparing above values it could be identified that the mean value of industry perception about graduates who have engaged in university extracurricular activities are higher than the mean value of industry perception about graduates who have not engaged in university extracurricular activities by 0.72345 . Therefore, it could be recognized that industry believes graduates who have engaged in university extracurricular activities are equipped with more skills, personal qualities and create a better perception to some extent than graduates who didn't engaged in university extracurricular activities. 
Table 05: Descriptive statistics of selecting for $\mathrm{HR}$ related jobs in the industry

\begin{tabular}{|c|c|c|c|c|}
\hline & & & Statistic & Std. Error \\
\hline \multirow{13}{*}{$\begin{array}{l}\text { Have got a comparatively } \\
\text { smaller chance of being } \\
\text { selected for HR related jobs } \\
\text { in the industry }\end{array}$} & \multicolumn{2}{|l|}{ Mean } & 3.23 & 145 \\
\hline & \multirow{2}{*}{$\begin{array}{l}95 \% \text { Confidence Interval for } \\
\text { Mean }\end{array}$} & Lower Bound & 2.93 & \\
\hline & & Upper Bound & 3.52 & \\
\hline & \multicolumn{2}{|l|}{$5 \%$ Trimmed Mean } & 3.22 & \\
\hline & \multicolumn{2}{|l|}{ Median } & 3.00 & \\
\hline & \multicolumn{2}{|l|}{ Variance } & .846 & \\
\hline & \multicolumn{2}{|l|}{ Std. Deviation } & .920 & \\
\hline & \multicolumn{2}{|l|}{ Minimum } & 1 & \\
\hline & \multicolumn{2}{|l|}{ Maximum } & 5 & \\
\hline & \multicolumn{2}{|l|}{ Range } & 4 & \\
\hline & \multicolumn{2}{|l|}{ Interquartile Range } & 1 & \\
\hline & \multicolumn{2}{|l|}{ Skewness } & -.268 & .374 \\
\hline & \multicolumn{2}{|l|}{ Kurtosis } & -.408 & .733 \\
\hline \multirow{13}{*}{$\begin{array}{l}\text { Have got a comparatively } \\
\text { bigger chance of being } \\
\text { selected for HR related jobs } \\
\text { in the industry }\end{array}$} & \multicolumn{2}{|l|}{ Mean } & 3.48 & .113 \\
\hline & \multirow{2}{*}{$\begin{array}{l}95 \% \text { Confidence Interval for } \\
\text { Mean }\end{array}$} & Lower Bound & 3.25 & \\
\hline & & Upper Bound & 3.70 & \\
\hline & \multicolumn{2}{|l|}{$5 \%$ Trimmed Mean } & 3.50 & \\
\hline & \multicolumn{2}{|l|}{ Median } & 4.00 & \\
\hline & \multicolumn{2}{|l|}{ Variance } & .512 & \\
\hline & \multicolumn{2}{|l|}{ Std. Deviation } & .716 & \\
\hline & \multicolumn{2}{|l|}{ Minimum } & 2 & \\
\hline & \multicolumn{2}{|l|}{ Maximum } & 5 & \\
\hline & \multicolumn{2}{|l|}{ Range } & 3 & \\
\hline & \multicolumn{2}{|l|}{ Interquartile Range } & 1 & \\
\hline & \multicolumn{2}{|l|}{ Skewness } & -.571 & 374 \\
\hline & \multicolumn{2}{|l|}{ Kurtosis } & -.207 & .733 \\
\hline
\end{tabular}

Source: Survey data, 2015 
According to the table 05, mean value of graduates who have not engaged in university extracurricular activities getting smaller chance of being selected for HR related jobs in the industry are 3.23 while graduates who have engaged in university extracurricular activities getting a higher chance of being selected for HR related job in the industry are 3.48 . There are 0.25 mean differences between those two groups. To identify the mean difference is significant or not researcher used paired sample-t tests and statistics found out are given below.

Table 06: Paired sample statistics of graduates who have engaged in extracurricular university activities and who haven't engaged in extracurricular activities

\begin{tabular}{|ll|l|l|l|l|}
\hline & \multicolumn{1}{|c|}{ Mean } & \multicolumn{1}{c|}{$\mathrm{N}$} & Std. Deviation & Std. Error Mean \\
\hline \multirow{3}{*}{ Pair 1 } & $\begin{array}{l}\text { Engaged } \\
\text { Not }\end{array}$ & 3.8000 & 40 & .36259 & .05733 \\
& Engaged & 3.0795 & 40 & .59602 & .09424 \\
\hline
\end{tabular}

Source: Survey Data, 2015

As per the table 06, mean values of graduates who have engaged in university extracurricular activities and who didn't are 3.8000 and 3.0795 respectively.

Table 07: Paired sample t-test of graduates who have engaged in extracurricular university activities and who haven't engaged in extracurricular activities

\begin{tabular}{|c|c|c|c|c|c|c|c|c|}
\hline & \multicolumn{5}{|c|}{ Paired Differences } & \multirow{3}{*}{$\mathbf{T}$} & \multirow{3}{*}{ Df } & \multirow{3}{*}{$\begin{array}{l}\text { Sig. (2- } \\
\text { tailed) }\end{array}$} \\
\hline & \multirow[t]{2}{*}{ Mean } & \multirow[t]{2}{*}{$\begin{array}{c}\text { Std. } \\
\text { Deviation }\end{array}$} & \multirow[t]{2}{*}{$\begin{array}{l}\text { Std. } \\
\text { Error } \\
\text { Mean }\end{array}$} & \multicolumn{2}{|c|}{$\begin{array}{l}\text { 95\% Confidence } \\
\text { Interval of the } \\
\text { Difference }\end{array}$} & & & \\
\hline & & & & Lower & Upper & & & \\
\hline Engaged & & & & & & & & \\
\hline $\begin{array}{l}\text { Pair } 1 \text { Not } \\
\text { Engaged }\end{array}$ & .72045 & .77588 & .12268 & .47232 & .96859 & 5.873 & 39 & .000 \\
\hline
\end{tabular}

Source: Survey Data, 2015 
The sig. value of paired sample t-test is .000 . Since the sig. value is less than 0.05 the mean difference of the above mentioned two pairs is significant. Therefore, it could be concluded that private sector organizations significantly believe that graduates who have engaged in university extracurricular activities have got more skills, has obtained good personal qualities and other relevant employability behaviors in comparison to graduates who have not engaged in such activities.

According to the Lawhorn (2008-09) for students planning to attend college or graduate school, extracurricular activities may improve their school-acceptance prospects. Extracurricular participation is often an indicator of students' ability to accept responsibility, manage multiple commitments and balance their pursuits of study, interest, and leisure. Kelinske, Mayer \& Chen (2001) stated that managers should concern with the perception of female and male employees who have participated in sports because sports can help individuals bring necessary skills such as goal setting, leadership, competitiveness, fair play, and networking to the workplace.

Current study output is also agreed with above results. Some questions of the questionnaire were designed to identify the industry perception about the skills, personal qualities and other attributes of graduates who have engaged in extracurricular activities and who have not engaged in extracurricular activities. After analyzing aforementioned area in the questionnaire researcher found out that the industry perception about graduates who have engaged in university extracurricular activities is better than the perception about graduates who have not engaged in university extracurricular activities.

Therefore, it could be recognized that industry also believes that the extracurricular activities improve skills, personal qualities and other attributes of people. 
Table 08: Paired sample statistics of being selected for a HR related job in the industry

\begin{tabular}{|l|l|c|c|c|}
\hline & Mean & N & $\begin{array}{c}\text { Std. } \\
\text { Deviation }\end{array}$ & $\begin{array}{c}\text { Std. Error } \\
\text { Mean }\end{array}$ \\
\hline $\begin{array}{l}\text { Have got a comparatively } \\
\text { bigger chance of being } \\
\text { selected for HR related jobs } \\
\text { in the industry } \\
\text { Pair 1 }\end{array}$ & 3.48 & 40 & .716 & .113 \\
$\begin{array}{l}\text { Have got a comparatively } \\
\text { smaller chance of being } \\
\text { selected for HR related jobs } \\
\text { in the industry }\end{array}$ & 3.23 & 40 & .920 & .145 \\
\hline
\end{tabular}

Source: Survey Data, 2015

According to the table 08, the mean value of graduates who have engaged in university extracurricular activities getting a chance of being selected for HR related jobs in the industry are 3.48 while the mean value of graduates who have not engaged in university extracurricular activities getting a chance of being selected for HR related jobs in the industry 3.23. There is a mean difference of 0.25 and to identify the mean different is significant or insignificant Paired sample-t test method was used and results are given below.

Table 09: Paired sample t-test of being selected for a HR related job in the industry

\begin{tabular}{|c|c|c|c|c|c|c|c|c|}
\hline & \multicolumn{5}{|c|}{ Paired Differences } & \multirow[t]{3}{*}{$\mathrm{t}$} & \multirow[t]{3}{*}{ df } & \multirow{3}{*}{$\begin{array}{l}\text { Sig. (2- } \\
\text { tailed) }\end{array}$} \\
\hline & \multirow[t]{2}{*}{ Mean } & \multirow[t]{2}{*}{$\begin{array}{c}\text { Std. } \\
\text { Deviation }\end{array}$} & \multirow[t]{2}{*}{$\begin{array}{l}\text { Std. } \\
\text { Error } \\
\text { Mean }\end{array}$} & \multicolumn{2}{|c|}{$\begin{array}{c}95 \% \\
\text { Confidence } \\
\text { Interval of the } \\
\text { Difference }\end{array}$} & & & \\
\hline & & & & Lower & Upper & & & \\
\hline $\begin{array}{l}\text { Have got a comparatively } \\
\text { bigger chance of being } \\
\text { selected for HR related jobs in } \\
\text { the industry - Have got a } \\
\text { comparatively smaller chance } \\
\text { of being selected for HR } \\
\text { related jobs in the industry }\end{array}$ & .250 & 1.354 & .214 & -.183 & .683 & 1.168 & 39 & .250 \\
\hline
\end{tabular}

Source: Survey data, 2015 
The p-value (sig.) of paired sample t-test is .250 . Since it is greater than 0.05 , the mean difference of above mentioned two pairs are insignificant. Therefore, it could be identified that engaging extracurricular activities is not a significant reason to select for a HRM related job in the industry.

Bommer, Timothy \& Boldwin (2002) found that extracurricular profile (clubs over athletics, importance of leadership role) most predictive of interpersonal skill performance. Recruiters likely improve their "payoff" by putting a premium on candidates who have taken certain types of leadership positions and by focusing on activities that have the greatest alignment with the types of skills they are seeking and also extracurricular experiences are relevant to career success because they teach and develop appropriate skills. According to Greenbank (2015) cited evidence from Hinchliffe and Jolly (2009) discovered that employers are only interested in sporting and cultural activities that demonstrate students possess skills relevant to employment, such as leadership and the ability to work in a team. It has also been suggested that particular types of sporting and cultural activity may have higher value in the graduate labor market.

But the current study gives a different outcome than above mentioned literature. Through this study researcher found out that in Sri Lankan context engaging extracurricular activities is not a significant reason for being selected for a HR related job.

Dynamic, team player, self-motivated, and results oriented were commonly and very frequently expected four personal qualities from graduates by the organizations irrespective of different HRM jobs in Sri Lanka (Opatha \& Arulrajah, 2012). But, according to the current study, researchers found out that even though the industry believes that the graduates who have engaged in extracurricular activities are equipped with more aforementioned skills, personal qualities and other attributes which are expected by the industry at the entry level job in HRM field, they have not given a significant higher chance of selecting for a job in the industry. 
Table 10: Mean values of two pairs based on the industry

\begin{tabular}{|l|l|l|}
\hline \multicolumn{1}{|c|}{ Industry } & Not Engaged (mean) & \multicolumn{1}{c|}{ Engaged (mean) } \\
\hline Transport equipment & 3.00 & 3.70 \\
\hline Banking \& Finance & 2.84 & 3.92 \\
\hline Private services & 3.18 & 3.12 \\
\hline Printing \& Publishing & 3.64 & 3.64 \\
\hline Textiles \& Apparel & 3.09 & 3.86 \\
\hline Manufacturing & 3.07 & 3.79 \\
\hline Construction & 3.32 & 4.23 \\
\hline Healthcare & 3.45 & 3.91 \\
\hline
\end{tabular}

Source: Survey Data, 2015

Table 10 depicts the mean values of the perception according to the industry, for those who have engaged in extracurricular activities and who did not engage in extracurricular activities. When comparing mean values of every industry, there are higher or equal mean values for the graduates who have engaged in extracurricular activities than who did not engage in extracurricular activities. Therefore, it could be concluded that above mentioned industries believe graduates who have engaged in extracurricular activities are equipped with more skills, personal qualities and other relevant employability behaviors than graduates who have not engaged in extracurricular activities.

Printing and publishing (3.64), health care (3.45) are the industries which have higher mean values respectively for the graduates who have not engaged in extracurricular activities. Therefore those aforementioned two industries give a better recognition for the graduates who have not engaged in extracurricular activities. Construction (4.23), Banking \& Finance (3.92) are the industries which 
have given highest mean value respectively for the graduates who have engaged in extracurricular activities. Therefore, it could be identified that Construction, Banking and Finance sectors give higher recognition from above mentioned industries to graduates who have engaged in extracurricular activities.

\section{Table 11: ANOVA}

Engaged:

\begin{tabular}{|l|c|c|c|c|c|}
\hline & Sum of Squares & Df & Mean Square & F & Sig. \\
\hline Between Groups & 2.028 & 7 & .290 & 2.992 & .016 \\
Within Groups & 3.099 & 32 & .097 & & \\
Total & 5.127 & 39 & & & \\
\hline
\end{tabular}

Source: Survey Data, 2015

According to the table 11, sig value is 0.016 and it is less than the tested Alpha value $(\alpha)$ of 0.05 . Therefore, the researcher proves that the model is significant at $95 \%$ confidence level. Then it could be concluded that the industry is significant for undergraduates who have engaged in university extracurricular activities and the industry perception about undergraduates who have engaged in extracurricular activities is varying from industry to industry.

\section{Table 12: ANOVA}

Not Engaged:

\begin{tabular}{|l|c|c|c|c|c|}
\hline & $\begin{array}{c}\text { Sum of } \\
\text { Squares }\end{array}$ & Df & $\begin{array}{c}\text { Mean } \\
\text { Square }\end{array}$ & F & Sig. \\
\hline Between Groups & 1.659 & 7 & .237 & .622 & .734 \\
Within Groups & 12.196 & 32 & .381 & & \\
Total & 13.854 & 39 & & & \\
\hline
\end{tabular}

Source: Survey Data, 2015

According to the table 12, Sig value is 0.734 and it is higher than the tested Alpha value $(\alpha)$ of 0.05 . Therefore the researcher proves that the model is insignificant at 95\% confidence level. Then it could be concluded that the industry is insignificant 
for undergraduates who have engaged in university extracurricular activities and the industry perception about undergraduates who have not engaged in extracurricular activities is not varying from industry to industry.

\section{Conclusion and Recommendations}

The current research focused towards the identification of value given to the university extracurricular activities in a selection process for HR related job. Main objective of the study was to identify whether there is a significant value given to the graduates who have engaged in university extracurricular activities in the selection process for HR related job.

For the purpose of collecting primary data, questionnaire is developed and pre-tested by the researchers based on the skills and personal qualities need to perform HR related job which were stated at Opatha \& Arulrajah (2012). It was distributed among officers who are directly engaging in the selection process in 40 private sector organizations.

The primary data collected through the questionnaire were statistically analyzed using descriptive statistics, paired sample t-test and ANOVA test with the aid of SPSS 20.0.

When analyzing industry perception about graduates, researcher found out that private sector organizations significantly believe that graduates who have engaged in university extracurricular activities have got more skills, good personal qualities and other attributes than graduates who have not engaged in extracurricular activities.

Furthermore, the researcher identified that the industry is significant for undergraduates who have engaged in university extracurricular activities in other words the perception about undergraduates who have engaged in extracurricular activities is varying from industry to industry. But also researcher found that the industry is insignificant for undergraduates who have engaged in university extracurricular activities it means the perception regarding undergraduates who have not engaged in extracurricular activities is not varying from industry to industry. 
When analyzing the graduate's chance of selecting for a HR related job researcher recognized that engaging extracurricular activities is not a significant reason for get selected for a HR related job in the industry.

Through this study Researcher identified that Printing and publishing, healthcare are the industries give a better recognition for the graduates who have not engaged in extracurricular activities. And also Construction, Banking \& Finance are the industries give higher recognition graduates who have engaged in extracurricular activities

According to these findings, organizations can implement a selection process which focuses to select candidates who have been engaged in university extra-curricular activities since they are equipped with more skills, personal qualities and other attributes. Their performance will contribute to achieve organizational goals effectively.

Since findings revealed that engaging extracurricular activities is not a significant reason for get selected for a HR related job in the industry, future candidates should pay more attention on the skills which are required when facing an interview and to get a higher chance of being selected for a job.

This study revealed the industries which give more recognition for graduates who have engaged in extracurricular activities. Those are Construction, Banking and Finance. The potential candidates who have been engaged in extracurricular activities can focus on to the jobs which are available in aforementioned industries. Moreover, to this the finding revealed that printing and publishing, health care industries have been identified as industries which give higher recognition for the graduate who have not been engaged in extracurricular activities. The potential candidates who have not been engaged in extracurricular activities can focus on to the jobs which are available in aforementioned industries.

Researcher collected data only from organizations which are situated in Western Province and also from limited industries. Therefore, it might not represent whole characteristics of the population. If the research sample covered every industry, 
findings would applicable for whole private sector organizations in Sri Lanka. Therefore it could be identified as a limitation of this study.

This study provide directions for researchers to do their future studies to identify what factors would give an added advantage for graduates to getting selected for a HR related job and also to identify why the industry is not awarding a significant value to graduates with higher skills, personal qualities and other relevant attributes.

\section{References}

Arulrajah, A., \& Opatha, H. H. D. N. P. (2012). An Exploratory Study on Entry Level HRM Job Opportunities and Their Requirements in Sri Lanka. Sri Lankan Journal of Human Resource Management, 3, 58-77.

Greenbank, P. (2015). "Still focusing on the "essential 2:1": exploring student attitudes to extracurricular activities". Education + Training , 184-203.

Hashim, J. (2012). Academic excellence as selection criteria among Malaysian employers. Higher Education, Skills and Work-Based Learning, 2, 63-73.

Kelinske, B., Mayer, B. W., \& Chen, K. L. (2001). Perceived benefits from participation in sports: a gender study. Women in Management Review , 7584.

Lawhorn, B. (2009). Extracurricular activities. Occupational Outlook quarterly, 1621.

Opatha, H. H. D. N. P. (2012). Human Resource Managemnt. Author, Colombo.

Opatha, H., \& Arulrajah, A. A. (2012). An Exploratory Study on the Personal Qualities/Characteristics expected by the Organisations for Key HRM jobs in Sri Lanka. Sri Lankan Journal of Human Resource Management, 32-48.

Peppas, S. c. (2002). Job Selection Criteria: A Study of Subcultural Differences in Perception. Equal Opportunities International , 1-12.

Raybould, J., \& Sheedy, V. (2005). Are graduates equipped with the right skills in the employability stakes? Industrial and Commercial training , 259-263. 
Robert, S., Rubin, William, H., Bommer, Timothy, T., \& Baldwin. (2002). USING Extracurricular Activity as an Indicator of Interpersonal Skill: Prudent Evaluation or Recruiting Malpractice? Human Resource Management , 441454.

Wilson, N. (2009). Impact of Extracurricular Activities on Students. 1-39. 